\title{
Opening Minds: Style Copies as Didactical Initiators
}

\author{
Michael Ahlers \\ Leuphana University of Lueneburg \\ michael.ahlers@leuphana.de
}

\begin{abstract}
First, a general overview of the German institutional music teaching system is given, and pedagogical history and recent developments are described. After that the special situation and needs of higher education are illustrated. The article proposes alternating phases of analysis and re-production of popular music as a reasonable way to introduce new students to their first year of studies. Using the hermeneutical helix as one basic idea, and the idea of style copies as a second, it can be shown that this works quite well. Students trained within such a framework are highly motivated, use both informal and formal learning strategies, and reflect on the processes, their groups, and their personal development. The argument is supported by data derived from a five-year study of written material.
\end{abstract}

KEYWORDS: history of popular music education in Germany, problem-based-learning, hermeneutics, style copy, learner-centred design, evaluation, informal learning

\section{Introduction $^{1}$}

At present in Germany a large variety of institutions offer educational programs on popular music. These range from primary and secondary education to lessons in music schools and music conservatories, as well as university courses or commercial providers offering different sorts of diploma. More than forty institutions of higher education, 900 public music schools, and hundreds of private music studios are providing education of this sort, not counting specialized jazz departments. The focuses of these institutions range from general 
education through instrumental training and the training of music production and business skills. This large number of institutions is likely motivated in part by popular music's arrival within interdisciplinary academic discourses and by its appreciation within German society as an important sociocultural, aesthetic and economic field. Yet on the other hand, a great number of commercial stakeholders try to get their "slice of the pie" by offering occasionally dubious certificates.

Within Germany's general music education, popular music has already been discussed as a pedagogical issue for more than fifty years (Maas and Terhag 2010). Yet it took quite some time to integrate popular music into primary and secondary education curricula as a matter of course. This was on the one hand due to the reverberation of post-Adornian debates on the aesthetic quality and purpose of popular music itself (Adorno and Simpson 1941) and of critical theory's pessimistic view of music business and its strong influence within music education. On the other hand, music educators were - and some still are today mostly classically trained on their instruments and voices. So there was a big divide between the teacher's and the pupil's experiences and competencies in analyzing, playing and even listening to popular music. In the 1980s, concepts emerged that dealt with the integration of the student's perspectives (Niermann 1987, Schütz 1982). These concepts focused on action-oriented approaches, which mostly implied music making. Some authors mocked this so-called "school pop music" since it consisted very often of basic and simplified arrangements, played on Orff instruments or other sound generators that weren't able to produce any of the sounds or experiences comparable to the original popular music students knew very well (Terhag 1991).

Newer concepts integrate popular music with aesthetic education and theory (Wallbaum 2009, Rolle 1999), communication and constructivist theory (Orgass 1996, Krause 2008) and Edwin Gordon's music learning theory, as well as with gender studies. This plurality sometimes makes it hard to name a theoretical mainstream at the moment. This might be more understandable if one knew that in Germany, education in general is a state-specific subject. This means that every federal state can work out specific curricula, as there are no national standards. Yet over the past year or so there has been an on-going development towards a new way of exchange and communication between, on the one hand, the specialized group of researchers on popular music, and on the other hand, the professional dissemination of facts and findings through music educational researchers and teachers alike. So it seems predictable that the latest ideas from postcolonial and democracy studies, or de-constructivist and post-hermeneutical theories, will be integrated more quickly into forthcoming curricula if both sides agree on their power and sustainability.

In higher education, it took years longer for popular music (studies) to arrive in universities and conservatories. But within the past ten years or so there has appeared an increasingly high number of undergraduate and graduate-level seminars, and even specialized programs, that focus exclusively on popular music or popular music studies. Such approaches and courses are based on various academic fields such as (ethno-) musicology, performing arts, media studies, sociology, literature, and others. Most recently, interdisciplinary or transdisciplinary research designs and findings (involving the integration of non- 
academics such as artists into interdisciplinary designs) have been published within the German scientific community. By now there are more than forty institutions on the market, ranging from university to franchised programs on music or media production and instrumental music or vocal training. So the field is very lively and sometimes contradictory.

\section{Theoretical backgrounds and aims}

The structure of our project seminar was developed, evaluated and optimized at the University of Paderborn in an undergraduate program called Popular Music and Media. Students at the University typically come from all over Germany, bringing various sociocultural and practical backgrounds. These students finish their bachelor studies within six semesters. So there is little time to cover the wide spectrum of material which the curriculum asks to be taught, including: popular music studies topics; economics; music theory; music production; journalism, and more.

The aim of such a scenario is to invoke student's motivation for the academic fields and methods at an early stage of their studies. And furthermore, the basic concept of empowerment, following Julian Rappaport (1981, 1994), is fundamental. The latter theory serves as a basis on which every student should experience a good sense of coherence in his or her academic career, in this example within different communities of practice. If people do so, their motivation, stress-related conditions, study efforts and overall well-being tend to better. This will be referred to again later in the paper.

In the first year of study the following design was used, based on two fundamental theoretical principles: first, the basic ideas of philosophical hermeneutics following mainly Hans-Georg Gadamer (1990), and second, the ideas of John Dewey (1916, 1938) and Karl Frey (2010) concerning problembased-learning (PBL) or the "project method".

\section{Inside: Hermeneutical structure}

The basic concerns of philosophical hermeneutics are understanding, knowledge and meaning. It reflects on a person's way of thinking, arriving at insights, gaining experiences, etc. Serving as a universal model of how knowledge, understanding and "truth" are created, it takes into account the previous knowledge and preconditions of every researcher, learner, and the process of the analysis or reading itself (Richter 2012). This also means that any subject influences the object she or he is referring to or analyzing. And this process of analysis affects the subject as well. As the subject understands more of the object, the object is better understood and therefore itself changes concerning its perception or being. The most common example for this would be a dialogue between two entities. These can both be subjects and objects, passive and active actors within a given process. The best-known illustration is a circle or helix of this hermeneutical process. 
FIGURE 1: Basic hermeneutical circle/ helix. $\mathrm{S}=$ Subject, $\mathrm{O}=$ Object.

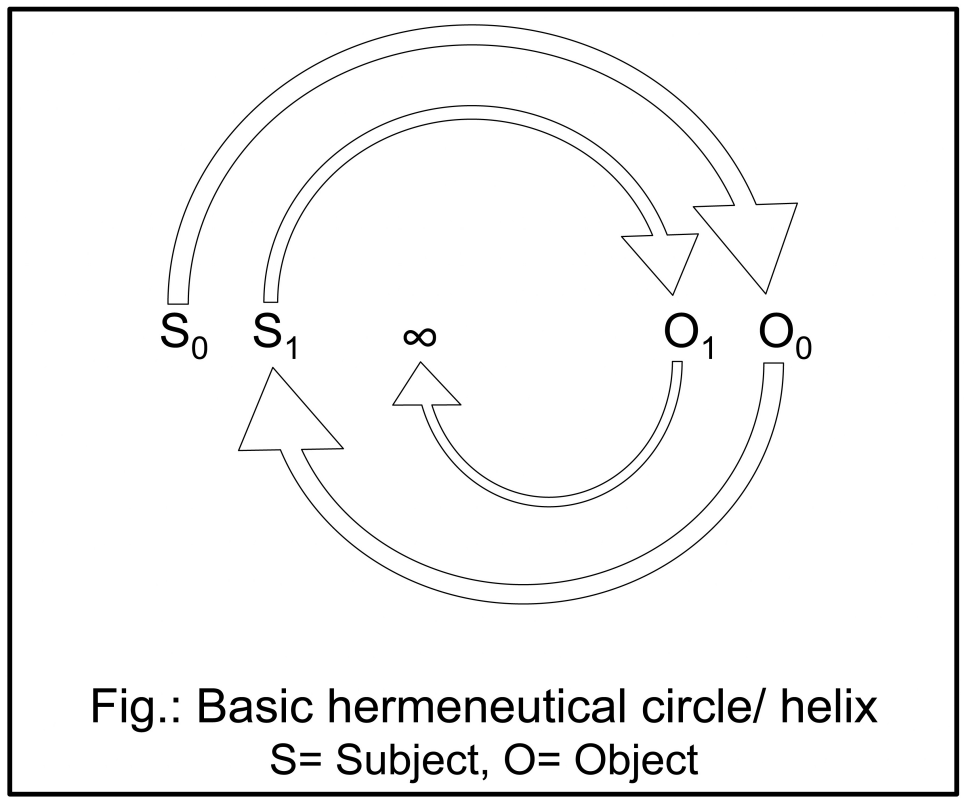

The process diagrammed in FIGURE 1 ends in the symbol of infinity, because one cannot say how many iterations are needed to reach a specific end or quintessence of an object or text. The main preconditions for this process - in Gadamer's theory - are openness, empathy, and the willingness to discuss and to reflect on one's self. Of course, there has been quite some critique on the philosophical approach of Gadamer, namely by de-constructivists such as Jacques Derrida or critical theorists such as Jürgen Habermas. Other theoretical approaches, such as discourse theory or constructivist theory, are able to extend hermeneutical ideas in different directions. Also, the underlying idea that every (aesthetic) object could be reduced or analyzed until one reaches its ultimate truth, meaning or sense, has been questioned. But, for the concept we wish to illustrate, the circle or helix idea in which prejudice and previous knowledge are well-integrated is quite useful, because it implies different phases of activity and passivity, practical and theoretical work, and reflections of one's own experiences as well as reflection on the object one is thinking about or working on. Since students create their own ideas, shaping their musical and aesthetical processes themselves, one could say that inside this hermeneutical process there is also an integration of constructivist theory; most of the phases are learner-centered, using their autopoietic power to invent, shape or present ideas.

To illustrate this more vividly, it would be best to imagine a student who is asked to solve a rather complex task within a group of previously-unknown collaborators. Every learner starts with his or her own prejudices, sometimes-naïve knowledge, skills, beliefs and language. They will always tend to choose from skills or competencies they feel familiar and confident with, and try to communicate their findings within their group on the basis of these familiar reference points. Inside the project circle, the groups will be given feedback on their work, and will be shown new methods or ways to think about certain 
aspects of their work or analysis. This always adds new perspectives and opens up their minds in preparation for various academic discourses that they normally will be introduced to later in their studies.

This also touches on questions of musical identity. Following Simon Frith (1996), it may be said that students undergo a process of self-positioning, choosing, and using musical identities while working on their "style copies" (integrating music, lyrics, performance, and aspects of music business) over a given period of time. These are also aspects they have to reflect upon after finishing their own productions.

\section{Outside: Project method}

We propose that the best framework for such complex and time-consuming tasks over a longer period of time is the project method or problem-based-learning (PBL). We prefer this framework because it includes many goals that are of current interest in educational debates; the structure is learner-based rather than teachercentered. Optimally, the problem itself serves as a magnet that attracts and suggests different materials and strategies. Actions and thinking processes should always be interlinked inside these projects (Dewey 1931: $97 \mathrm{ff}$. .).

There is empirical evidence that such learning arrangements have positive effects on the individual as well as the groups and the overall learning contexts involved. Karl Frey summarizes some the findings in his books. He reports that inside the project method, learners make extensive use of informal learning and peer-tutoring. They discover new knowledge and topics themselves, based on sometimes newly developed strategies or methods. This type of acquired knowledge is retained in memory longer, and can also be transferred more effectively. Furthermore, divergent and other creative thinking strategies are more often used than in conventional learning environments. Participants in such groups must set their own milestones and goals, and are therefore responsible for taking good care of things like time- and self-management and further soft or social skills. Finally, weaker learners or introverted and anxious personalities are better integrated into learning processes, and their sense of coherence is stronger as all members of one group need to be team-minded to reach their goal (Frey 2010: 183-184). This was one big advantage of the project method, as the theory of empowerment was followed to support every learner and every individual's way from the start of his or her studies.

\section{Style copies as didactical initiators}

Style is a replication of patterning, whether in human behavior or in the artifacts produced by human behavior, that results from a series of choices made within some set of constraints. (Meyer 1989: 3)

Styles (St): historical periods, cultural movements, authors or groups of works: that is, the particular ways in which MT [music technique], SP [social practices], and GC [general codes] are concretely realized. (Brackett 2000: 12) 
The term "style copy" is a literal translation of the German expression Stilkopie and it might be a bit misleading for English readers. To point out the main idea of "doing style copies" as a set problem or didactical initiator, it could be useful to first define the term itself. First, in Germany "style" commonly stands for an artist's personal style, his or her artistic persona, performance, looks, signature sounds/licks or sound logos (Diedrichsen 2008) and so forth. Secondly, style is also often taken to indicate genre - such as rock' $n$ 'roll, Motown or dubstep - and its commercialization (Wicke at al. 2007: 697). So this seems quite compatible with Brackett's definition. In other academic discourses, definitions are even more sophisticated. Some researchers still like the idea of popular music "levels" as developed by Richard Middleton (1990), which differentiates between style, genre, idiolect and performance. Others integrate the concept of style within a network (Herbst 2015) or system theory of popular music. Compared to topics such as sound, methods of analysis, performance, or authenticity, style itself is an academic term that seems to be rather well treated in the current literature, albeit with a certain amount of disagreement on certain points.

Yet there is little academic tradition in "doing style copies" of popular music. Style copies are - historically and today - mainly used at music conservatories: to practice different compositional or notational concepts, to explore music theory, and to use musical resources or instrumentation correctly (Kühn 2010: 16). This is somewhat astonishing, as the action of "copying" or imitation seems to be one major approach or method within popular music cultures. One could say that it almost starts when standing in front of your bedroom mirror with a hairbrush or a tennis racket in your hands while playing and imitating your favorite artists. As Lucy Green (2002: 23-24) illustrates, these important informal learning processes normally start by attentive or purposive listening to records or band mates in the practicing room. She summarizes:

\begin{abstract}
Musicians watch and imitate each other as well as more experienced players, they talk about music and they form bands at very early stages. Through such interaction they copy and exchange ideas, knowledge and techniques, learn to play together, including making covers, improvisations and compositions of original music. All their listening and copying activities feed into both their individual and their group music-making. (ibid.: 97)
\end{abstract}

Jan Hemming (2002, 2003) and Claudia Bullerjahn (2003) also researched processes of informal learning and creative strategies within band contexts. Their findings stress the importance of specific types of deliberate practice, purposive listening, jamming, and especially the imitation of popular music stars and styles. And finally, Ralf von Appen (2003: 86) sums it up by stating that the ears were always the best teachers for aspiring popular musicians, and that imitation was a suitable way for most of the best-known artists to learn and later build on their own musical identity or originality. Besides one article by Gullberg (2010), there are few findings or concepts on formal teaching of popular music that relate to comparable theoretical foundations. Some of the aspects described in Gullberg's article - such as spontaneous and informal processes, negotiation of opinions and views, mutuality and equality - also take place inside the methods described in this article, or they are goals we try to aim at in our own work. Contrary to the 
situation described by Gullberg, students in these types of study programs are not for the most part aiming at becoming popular musicians, but rather wish to make a different kind of living inside creative industries, becoming music promoters, journalists, tour managers or likewise. So the focus on "making music by ear" (Gullberg 2010: 128) is not of major interest to the students. It is just one important aspect alongside several other skills, forms of knowledge, and competencies one needs to develop while trying to understand popular music (artists, business, aesthetics, etc.) as a whole.

Nevertheless, style copies themselves have quite a long and well-documented history and importance within popular music. They are central to the development and expertise of many musicians. This becomes evident when studying biographies of artists or studies of songwriters and their strategies and forms of expertise such as the one by Paul Zollo (2003). Furthermore, style copies include different processes of analysis and production that touch upon various academic fields and findings. Because they represent such a "real" and vital activity, they are considered by us to be a good tool, object, or problem to initiate learning as well as creative processes in higher education.

\section{Exemplifying the project circle}

FIGURE 2: Concept of the project.

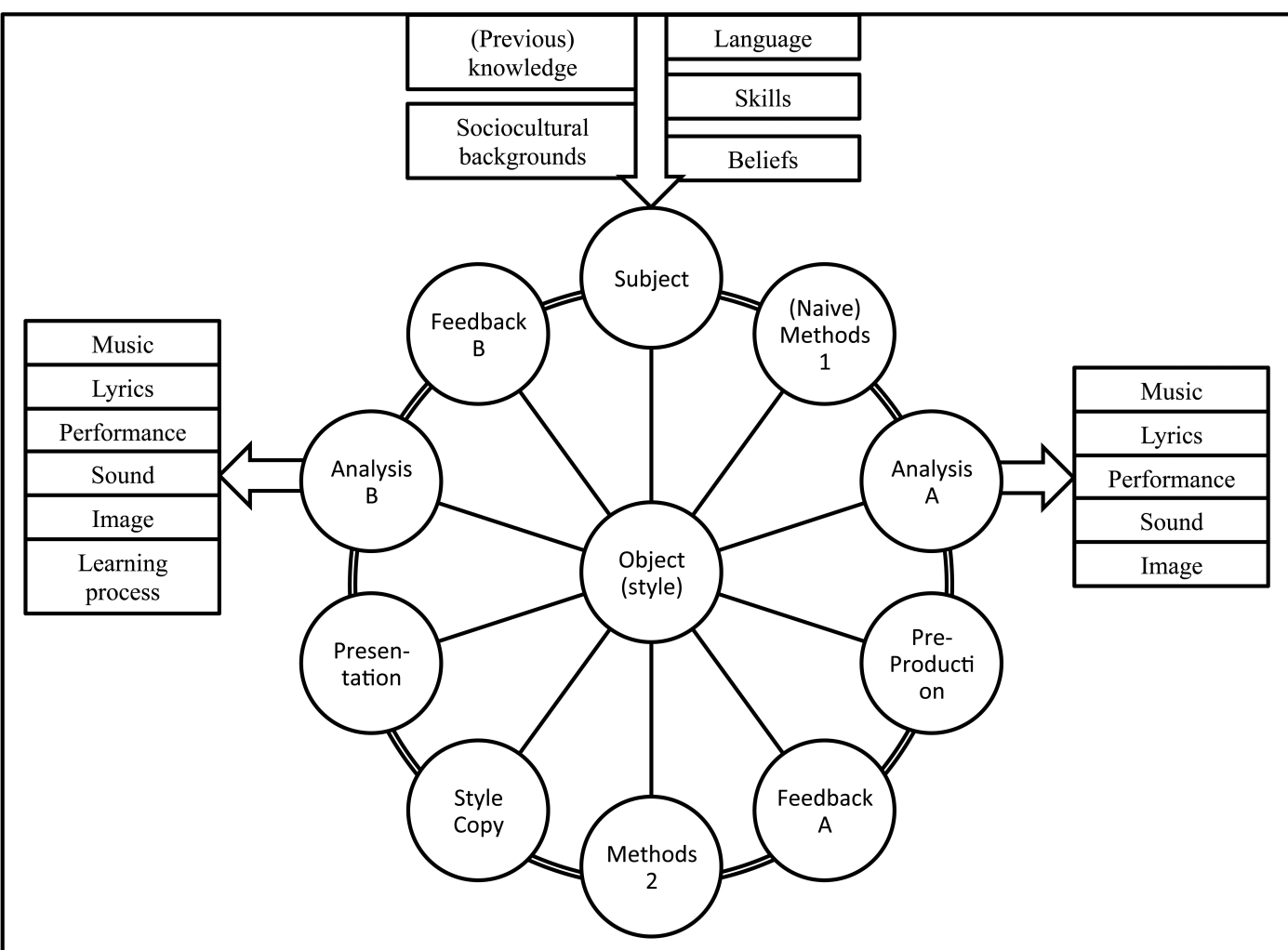

Fig.: Concept of the project 
As a first step, study groups choose from different styles they will try to copy or work on. Over the past seven years there has been a total of forty-two styles they could choose from. Two preferably diverse artists and songs represent each given style. For example, for "dancehall" there was one German and one Jamaican track, each using specific idioms, performances, sounds, and artistic personae. For "piano ballad" students could pick a song by Billy Joel or Tori Amos. B.B. King and Robert Cray represented "blues" in one year; "funk" tunes were by Charles Wright or Prince, and so forth. Of course, two songs do not represent one whole style nor the genre's history, sociocultural development, etc. But this is not the main idea of the style copy concept. The groups should pick one song or artist that they are attracted by, without knowing too much about it at first. ${ }^{2}$

Hermeneutical theory distinguishes between "subtilitas intelligendi", "subtilitas explicandi", and "subtilitas applicandi". These designate different phases of thinking, explaining and doing, which also means the alternation of analysis, production, and reflection. So, after a group has chosen a specific style they split up their work on analyzing the material. This is mostly done using their skills and competencies and sometimes vernacular methods they already know or bring in. In this analysis they are asked to analyze or describe the harmonic patterns, song structure, rhythm, tempo, instruments, lyrics, image of the specific artist in relation to the genre, sound specifics, performances, and sociocultural as well as technical aspects they can find. This phase takes quite some time and students hand in their findings afterwards. Also, the processes of group building and choosing or using musical identities (for example: to be "the metal-head" or the "lyricist") are timeconsuming too. While some of the findings are pretty eloquent and original, some of them are maybe just copied and pasted from a Wikipedia article or likewise. So the overall quality of outcomes can hardly be predicted.

Based on this analytical work, the groups prepare a MIDI layout or "preproduction" of their own style copy. After that, a lecturer/scholar gives them feedback on their recent work. This includes hints for further readings and methods they could apply later. It seems important to stress the fact that their own style copies are originals. They do not try to exactly copy one of the given songs, but to pick the sound, attitude or other aspects they are focusing on in their copies. Over the past years, some ideas and basic readings have become central to this PBL on style copies: for instance, in the analysis and the planning of a chosen style the model of the sound-box (Dockwray and Moore 2010) appeared to be really helpful. This model focuses both on listening and production activities. It can also initiate debates on sound-specifics, instrumental and vocal placements, panorama positioning, signal processing techniques such as reverb, and more. Another important issue was the analysis of persona and performances (Auslander 2004, Moore 2012) or the musical meaning and sounds of recorded music (Zagorski-Thomas 2012, Binas-Preisendörfer 2008). Since these scientific resources and theories often weren't included within their first year curriculum, it was striking how much devotion and motivation students showed when they were given these tips.

After this important stopover, the groups then apply their newly acquired knowledge and skills when starting on the production of the main style copy. They are asked to record one song, possibly supported by the production of a press kit for this virtual musician or group, or to hand in a video at their final 
presentation. In this phase there was also peer tutoring, for example to help in music production. This pedagogical idea was introduced after noticing an article by Don Lebler (2007), which reported on good effects and new learning scenarios associated with peer tutoring.

The presentational setting for projects differed from one occasion to another. Sometimes projects were staged as a showcase performance for music industry professionals, while in other cases a virtual artist and repertoire manager were role-played as being in town to pick one or two new ideas for his or her product portfolio. Students were asked to act in their roles as artists, in order to switch over from analytic and productive phases to play theory approaches. As part of this process, they have to reflect on the meaning of authenticity as a key concept in the marketing of popular music. So if they presented a folk song, for example, presentation would significantly differ from presenting a different style such as rap or heavy metal.

It should be a fun thing for them to present their hard work of the past months. The last steps of the project circle include a final analysis of their own style copy, a comparison to the original song or artist, and a reflection on their learning processes and on their informal learning experiences. To finish the project, all students were given individual feedback on their findings and learning processes as well as a judgment or rating of the final style copy of their group.

\section{Evaluation: methods and findings}

The design of the style copy-projects was evaluated continuously. Besides the integrated and outcomes based process of evaluation which the University itself offers for every seminar, a meta-analysis or explorative evaluation of the written material was also performed. This includes both first and final analysis papers, as well as reflections on the seminar structure, time or social issues inside the group's organization, and so forth. A total of close to 300 papers representing a period of five years were closely inspected. Data was summarized using qualitative content analysis methods following Philipp Mayring (2002) to merge and accentuate central topics or categories.

\section{First papers}

Within their first papers, students only concentrate on the given material and usually do not reflect on their learning or on group processes. Due to this, the main topics tend to focus on the analysis of the required parameters and materials, as mentioned earlier. There is significant variation within the student findings at this phase. These range from excellent analysis of harmonic patterns through lyrical and music production aspects. This makes sense given the group's heterogeneity; students in this programme are aged twenty-one through thirty, some of them already having various experiences as musicians, freelance producers, or serving other roles inside creative industries. Some of the findings are inspiring as they add new or unexpected perspectives or insider's knowledge to certain parameters, and reveal unanticipated levels to a given style or artistic concept. On the opposite side, there is also a large number of rather naïve texts, 
mainly referring to online resources. As the first papers are written in a group, they are always combined in one document. Unfortunately, these rarely seem to be recapitulated or revised before handing them in. That is a reason why the variation in the beginning is so high. Hence, an instruction could be helpful asking the group to discuss and maybe adjust their first findings before handing them in.

On the whole, the papers are needed to help students choose appropriate further readings and individual methods. Every group needs specific resources based on their strengths and weaknesses, as well as on the recent or previous knowledge they were able to present in their first papers.

\section{Final papers}

Final papers are written individually at the end of the whole process. They are far more interesting to evaluate than the first papers. Central categories and topics inside this material are:

- Style copy as a topic itself

In this category the style copies themselves are picked up. Papers focus on aesthetic questions and on the meaning of style and music. Most of the material of our evaluation tends to be positive, yet students are very self-critical concerning weaknesses of their own copies or ideas. Aesthetic issues and discussions of these are based on comparisons with the original tunes as well as on personal emotionbased judgements. Two stressed aspects are: first, their own performance is often considered to be less acceptable than the original, and second, the idiom or persona of the virtual artists they tried to develop over this rather short period of time are often said to have room for improvement.

\section{- Group processes}

Students often report on communicational and organizational challenges and problems inside their groups. These processes seem to be crucial to aspects such as their experienced sense of coherence and the outcomes at the end of the style copy projects. Besides some critical aspects mentioned below, the overall tendency is that mutual and equal work could be established, once their identities or roles were chosen. Secondly, music production and technical issues inside the groups are a big topic. Since it is mostly young men dominating the groups by their knowledge or experience concerning technical or production aspects, female students tend to be rather disenchanted. Even though there was peer tutoring offered at the moments of production, women unfortunately weren't always as involved as men. This affects the overall judgements on the final outcomes, too. On the one hand, most of the papers claim it was a good experience, but on the other hand they propose that more democratic structures inside their groups could have been a way to enhance their style copy results. But some students also add that this might have ruined their time management.

- Individual processes

All the papers mention time-management and workload issues. Compared to a conventional seminar, these projects take more (individual) time to finish. The learner-centred approach hands over a lot of responsibility to the student. Also, 
processes of peer-tutoring and informal learning are time-consuming. As the students are in their first year of studies, they are often not familiar with such challenges. Here a big divide between students that come almost directly from schools, and elder students with vocational experience, can be spotted.

Though some of the papers criticise working processes inside their groups, nearly all of the papers take a positive view of their individual learning processes. Words like "pride" and "satisfaction" can be found very often when a student writes about his or her "own" style copy.

Also, students claim they were highly motivated. And statements can be found saying that the style copy project gave them a deeper understanding or consciousness of the relevance of theories and methods from popular music studies. Many papers deal with the importance of the mixture of practical and theoretical phases. This alternation apparently seems to be able to effectively "push them" through the hermeneutical circle and processes of self-assurance.

\section{Discussion}

Popular music, as a complex field or network of aesthetic, technical, economic, and cultural practices, and with various theories and disciplines working on it, often appears quite ornate to new students. Being motivated as fans, musicians, or likewise, they are easily frustrated when realising that there is such a large body of material, methods, and findings to analyse, produce, and reflect upon.

Problem-based-learning or project methods in higher education are highly qualified to frame learner-based education. As we tried to illustrate, the idea of doing style copies serves as a strong motivation and didactical initiator. Such an activity is so vital because imitation or copy processes themselves are crucial to artistic careers and expertise. The hermeneutical basis of the project's structure serves very well to highlight such aspects. As the evaluation showed, students positively judge their motivation during such a project. Also, some of the working groups continued making music together after finishing their style copy. Further, they are introduced to a variety of theories and methods over a rather short period of time. These never end in themselves, as they are applied to newer problems when analysing or re-producing a given style of popular music. Finally, some of the findings within the first and final papers were illuminating and well thought out.

Going one step beyond this project, one could imagine that the essential structure in which analytical phases are followed by active re-production and reanalysis phases could also be productive as a paradigm for academic research. This would mean academics from different disciplines could select one style, song, or performance and first apply their "native" methods and theories. After that, they would try to copy all the aspects found in their first analysis. This could lead to the need for newly developed interdisciplinary or transdisciplinary methodologies and it could also produce new insights and findings when reflecting on the production, the comparison, or the research process itself. So the proposed structure is to be understood as a theoretical framework which has been actively implemented, unfortunately at only one European university to date. We 
believe it could be able to integrate further processes and even research aims and topics, while focusing on teaching popular music.

\section{Endnotes}

${ }^{1}$ This article follows a paper presented by the author at a conference of the German Society for Popular Music Studies, together with Prof. Dr. Thomas Krettenauer.

2 A number of songs that were produced to date can be found at http://soundcloud.com/stilkopien-upb (Accessed: 25 February 2015).

\section{References}

Adorno, T. W. and Simpson, G. 1941. On Popular Music. Studies in Philosophy and Social Sciences 9: 17-48.

Appen, R. von. 2003. So You Want to Be a Rock'n'Roll Star. In G. Kleinen Ed. Begabung und Kreativität in der populären Musik. Münster: Lit: 69-90.

Auslander, P. 2004. Performance Analysis and Popular Music: A Manifesto. Contemporary Theatre Review 14(1): 1-13. http://dx.doi.org/10.1080/1026716032000128674

Binas-Preisendörfer, S. 2008. Rau, süßlich, transparent und dumpf - Sound als eine ästhetische Kategorie populärer Musikformen. Annäherung an einen populären Begriff. In K. Maase Ed. Die Schönheit des Populären. Ästhetische Erfahrung der Gegenwart. Frankfurt: Campus: 192-209. [Rough, Sweet, Transparent or Muffled - Sound as an Aesthetical Category of Popular Music. Approximation Towards a Popular Term].

Brackett, D. 2000. Interpreting Popular Music. $2^{\text {nd }}$ edition. Cambridge: Cambridge University Press.

Bullerjahn, C. 2003. Junge Komponierende in der zeitgenössischen Kunst- und Popmusik. In G. Kleinen Ed. Begabung und Kreativität in der populären Musik. Münster: Lit: 107-124. [Young Composers in Contemporary Art and Popular Music].

Dewey, J. -

1916. Democracy and Education. The Middle Works of John Dewey (Vol. 9).

Carbondale: Southern Illinois University Press.

1938. Experience and Education. The Later Works of John Dewey (Vol. 13).

Carbondale: Southern Illinois University Press: 1-62.

Diederichsen, D. 2008. Drei Typen von Klangzeichen. In H. Schulze Ed. Sound Studies: Traditionen - Methoden - Desiderata. Eine Einführung. Bielefeld: Transcript: 109-123. [Three Types of Sound Figures/Signs].

Dockwray, R. and Moore, A. 2010. Configuring the Sound-Box 1965-1972. Popular Music 29 (2): 181-197.

Frey, K. 2010. Die Projektmethode: Der Weg zum bildenden Tun. 11. Aufl. Weinheim: Beltz. [The Project Method - a Way Towards Educational Action].

Frith, S. 1996. Music and Identity. In S. Hall and P. Du Gay Eds. Questions of Cultural Identity. London: Sage: 108-127. 
Gadamer, H. G. 1990. Wahrheit und Methode. 6. Aufl. Tübingen: Mohr Siebeck. [Truth and Method].

Green, L. 2002. How Popular Musicians Learn. A Way Ahead for Music Education. Aldershot: Ashgate.

Gullberg, A.K. 2010. BoomTown Music Education. An Introduction. In C. F. Thorgersen and S. Karlsen Eds. Music, Education and Innovation. Pitea: University Press: 123-144. http://pure.ltu.se/portal/files/4915218/Festskrift.pdf. Accessed: 31 October 2104.

Hemming, J. 2002. Begabung und Selbstkonzept. Eine qualitative Studie unter semiprofessionellen Musikern in Rock und Pop. Münster: Lit. [Talent and Self Concept. A Qualitative Study Amongst Semi-Professional Rock and Pop Musicians].

Hemming, J., Kleinen, G. 2003. Karrierebeginn im Popsektor? Eine Tagebuchstudie. In G. Kleinen Ed. Begabung und Kreativität in der populären Musik. Münster: Lit: 49-68. [Career Starts in the Pop Sector? A Diary Study].

Herbst, J. 2015. Netzwerk Sound: Eine didaktische Herausforderung der populären Musik. Augsburg: Wißner. [Network Sound: a Didactic Challenge of Popular Music].

Krause, M. 2008. Bedeutung und Bedeutsamkeit. Interpretation von Musik in musikpädagogischer Dimensionierung. Hildesheim: Olms. [Meaning and Significancy: Interpretation of Music in a Music Educational Dimension].

Kühn, C. 2010. Musiktheorie lehren. Zu einer Umfrage an den deutschen Musikhochschulen. In Zeitschrift der Gesellschaft für Musiktheorie 7 (1): 11-60. [Teaching Music Theory. Findings From a Study in German Music Conservatories].

Lebler, D. 2007. Students-as-Master? Reflections on a Learning Innovation in Popular Music Pedagogy. International Journal of Music Education 25 (3): 205221.

http://dx.doi.org/10.1177/0255761407083575

Maas, G. and Terhag, J. 2010. Zwischen Rockklassikern und Eintagsfliegen. 50 Jahre populäre Musik in der Schule. Oldershausen: Lugert. [Between Rock Classics and Passing Crazes. Fifty Years of Popular Music in Schools].

Mayring, P. 2002. Qualitative Inhaltsanalyse. $8^{\text {th }}$ edition. Weinheim: Beltz. [Qualitative Content Analysis].

Meyer, L. B. 1989. Style and Music. Theory, History, and Ideology. Chicago: The University of Chicago Press.

Middleton, R. 1990. Studying Popular Music. Milton Keynes: Open University. Niermann, F. 1987. Rockmusik und Unterricht: Eigene Wege für den Alltag mit Musik. Stuttgart: Metzler. [Rock Music and Education: Own Ways/Strategies For Music in Everyday Life].

Moore, A. F. 2012. Song Means: Analysing and Interpreting Recorded Popular Song. Farnham: Ashgate.

Orgass, S. 1996. Kommunikative Didaktik. Ansätze zu einer ästhetischen und pädagogischen Begründung sowie zwei praktische Erprobungen. Augsburg: Wißner. [Communicative Didactics. Approaches Towards Aesthetical and Pedagogical Legitimations and Two Practical Samples].

Rappaport, J. - 
1981. In Praise of Paradox: A Social Policy of Empowerment Over Prevention. American Journal of Community Psychology 9 (1): 1-25.

1994. Empowerment as a Guide to Doing Research: Diversity as a Positive Value. In E.J. Trickett, R. J. Watts and D. Birman Eds. Human Diversity:

Perspectives on People in Context. San Francisco: Jossey-Bass: 359-382.

Richter, C. 2012. Musik verstehen. Vom möglichen Nutzen der philosophischen Hermeneutik für den Umgang mit Musik. Augsburg: Wißner. [Understanding Music. Possible Benefits of the Philosophical Hermeneutics for the Handling of Music].

Rolle, C. 1999. Musikalisch-ästhetische Bildung. Über die Bedeutung ästhetischer Erfahrungen für musikalische Bildungsprozesse. Kassel: Bosse. [Musicalaesthetical Education: The Meaning of Aesthetical Experiences for Musical Education].

Schütz, V. 1982. Rockmusik: Eine Herausforderung für Schüler und Lehrer. Oldenburg: Isensee. [Rock Music: A Challenge for Students and Teachers].

Terhag, J. 1991. Schul-Musik und Schüler-Musik: Zeitlos aktuelle Herausforderungen des Musikunterrichts zwischen Aufbereitung, Bewahrung und Zerstörung. In W. D. Lugert and V. Schütz Eds. Aspekte gegenwärtiger Musikpädagogik. Ein Fach im Umbruch. Stuttgart: Metzler: 226-238. [SchoolMusic and Student's Music: Up-to Date Challenges from Editing Through Conservation and Destruction].

Wallbaum, C. 2009. Produktionsdidaktik im Musikunterricht. Perspektiven zur Gestaltung ästhetischer Erfahrungssituationen. 2. veränderte Aufl. Dresden: Qucosa. [Production Didactics in Music Education. Perspectives for the Creation of Aesthetical Experiences].

Wicke, P., Ziegenrücker, W. and Ziegenrücker, K. E. 2007. Handbuch der populären Musik. Geschichte, Stile, Praxis, Industrie. Mainz: Schott. [Handbook of Popular Music. History, Styles, Practice and Industry].

Zagorski-Thomas, S. 2012. Musical Meaning and the Musicology of Record Production. In D. Helms and T. Phleps Eds. Black Box Pop. Analysen Populärer Musik. Bielefeld: Transcript: 135-147.

Zollo, P. 2003. Songwriters on Songwriting. Cambridge: Da Capo Press. 